\title{
Brand Experience: How Does It Affect Brand Personality and Brand Loyalty in the Egyptian Telecommunications Industry?
}

\author{
Amira M. Omar ${ }^{1}$ \\ ${ }^{1}$ Faculty of Economics and International Trade, Egyptian Chinese University, Cairo, Egypt \\ Correspondence: Amira M. Omar, Faculty of Economics and International Trade, Egyptian Chinese University, \\ Cairo, Egypt. E-mail: aomar@ecu.edu.eg
}

Received: March 11, $2020 \quad$ Accepted: April 30, $2020 \quad$ Online Published: May 9, 2020

doi:10.5539/ijms.v12n2p104 URL: https://doi.org/10.5539/ijms.v12n2p104

\begin{abstract}
Brand experience has received a lot of attention within the business industry. Customers are looking for not only valuable brand benefits but also, emotional skills as well as brand experience theory. In this regard, the Egyptian Telecommunications Industry tries, also, to provide answers on how to measure brand experience and how it affects customers' behaviors. This research examines in the context of the Egyptian telecommunications market the relationship between Brakus et al.'s (2009) four whole experience dimensions (sensory, affective, intellectual, and behavioral), brand personality, and brand loyalty. The author produced an online questionnaire, which, based on a simple sampling method, was distributed to and collected from the Egyptian telecommunications industry (Vodafone Egypt, Orange Egypt, Etisalat Egypt, and We Egypt). Four hundred fifty questionnaires were distributed and, excluding those that were incomplete, the author obtained 392 samples. This represented an $87 \%$ response rate.

The results indicate that brand experience has a positive impact on the brand's personality. Brand experience has, also, a strong positive effect on brand loyalty and, ultimately, brand personality has a strong positive effect on brand loyalty. Besides the brand experience's direct effect on brand loyalty, it has a significant indirect effect on brand loyalty by impacting on brand personality.

Among the relationships between the variables, the relationship between brand personality and brand loyalty is the strongest. More particularly, it is noteworthy that the correlation with the findings shows that the relationship between brand experience and brand loyalty is greater than the direct relationship. Therefore, in order to strengthen customer brand loyalty, telecommunications managers should pay more attention to customer brand personality.
\end{abstract}

Keywords: brand experience, brand loyalty, brand personality, brand attitude, Egyptian telecommunications market

\section{Introduction}

There has been a significant shift in today's market. We have moved from selling and promoting products and services to trading and engaging with customers through experience (Joy \& Fortified Wine, 2003). This conversion relates to the quantity of available products from which customers make their choices. There has been an enormous increase in the time that customers spend in making their purchasing decisions (Ekstrom, 2010). Riemann et al. (2010) state that customers start to feel satisfied when they are happy that their needs are being met. This happiness creates a need to fully understand across the whole purchasing process what has an impact on customers. Worldwide, most companies, which contain many brands, fight for their customers' loyalty. Therefore, it is becoming essential to have brand experience (Brakus et al., 2009).

Brand experience benefits from a great deal of thought in devising a strategy. Marketing professionals have begun to understand that the customers' experiences of brands are vital to the creation of marketing strategies for products and services (Shaw \& Ivens, 2002; Smith \& Wheeler, 2002; Schmitt, 2003; Chattopadhyay \& Laborie, 2005). Customer and marketing studies have shown that brand experience occurs when, in browsing products, buyers seek the best value in making their purchasing decisions. (Holbrook, 2000; Arnould, Price, \& Zinkhan, 2002; Brakus, Schmitt, \& Zhang, 2008). 


\section{Literature Review}

Brakus et al. (2009) provide a theoretical review and post-empirical research about the different value of brand experience when compared to similar brand definitions as well as brand involvement, brand attachment, consumer satisfaction, and brand assessment. Their findings indicate that, while the brand experience is different, it is linked to those structures.

In line with Schmitt (2003), customer satisfaction is characterized as an associated result-oriented viewpoint that arises when the customers consider that the product's output meets their expectations. In contrast, the related experience is defined as process-oriented, along with the functional, brand-driven predictors of customer satisfaction. Meyer and Schwager (2007) suggest that customer satisfaction results from a series of experiences where the level of satisfaction is quantified by the net results of good experiences minus bad experiences.

According to Fishbein and Ajzen (1975), customer attitudes are "learned dispositions to react to a given object in a consistently favorable or unfavorable manner." Brakus et al. (2009) suggest that, on the one hand, brand attitudes are generic brand decisions and, therefore, should be differentiated from brand experiences which, on the other hand, embrace unique sensations, feelings, thoughts, and behavioral reactions. They recognize that expertise can contribute to a general view of the product itself while, at the same time, it can reflect only a limited portion of the overall brand experience.

\subsection{Brand Experience}

As stated earlier, Brakus et al. (2009) suggest that there is complete expertise as shoppers obtain assistance in searching for goods or services, purchase them and use them. However, this follows once they have been subjected to either messages or advertising relevant to their preferences. Internal consumer reaction (feelings, perceptions, cognitive ability) and the behavioral reaction is caused by a brand-related stimulus that forms part of a company's style and image, advertisement, relations, and ecosystems (Brakus et al., 2009).

Brand experience is not a product, facility, or client assessment and is only a reaction to brand-related stimuli. Brand experience can be used as a precedent for product behavior. It can be characterized as the full evaluation of a brand based on its advantages and features and product recognition, and it can be explained as the increase in a brand's valuation (Japutra et al., 2014; Zarantonello \& Schmitt, 2013).

\subsubsection{Dimensions of Brand Experience}

Many templates seek to show the variables or attributes that mediate brand experience. Walls (2013) points out that there are difficulties in choosing which experimental structures and measurements to use for the research. This may be attributable to the multidimensional complexity of the experience (Manthiou et al., 2015).

Klaus and Maklan (2012) propose that primary determinants of expectations of service experience are user feedback, moments of reality, emphasis on consequences, and peace of mind since these influence customer satisfaction and loyalties. Roswinanto and Strutton (2014) assume that technical and conceptual structures precede brand experience. For instance, it is known that significant influences are the viewpoint that drives the brand, the content of the celebrity endorser, the messaging fit, the graphical image, the customers' attitudes towards the brand, and the uniqueness of the brand. As appropriate, Shamim and Mohsin Butt (2013) stress meanings, moral, relational, and non-utilitarian aspects. By comparison, Rageh Ismael et al. (2011) suggest that pricing, costs, ads, staff, business capability, core services, and word of mouth are primary indicators of a specific business or company interactions.

This research is based on the four dimensions of Brakus et al.'s (2009) four whole experience dimensions (Sensory, Affective, Intellectual, and Behavioral).

\subsubsection{The Sensory Dimension}

Numerous sensory experiences at the visual, auditory, olfactory, tactile, and sensory levels create touchpoints with customers (Schmitt, 2012; Zarantonello \& Schmitt, 2013). These experiences can involve a visual response to the name and logo or verbal phrases in brand colors. Sensory feedback concerning a good or service forms the perception and, hence, the trust in the business's reputation of being successful trust in delivering results. The effect shows the significance of this esthetic aspect for the differentiation and, more especially, since functional attributes, such as price and quality in differentiation strategies, have become less relevant (Cho et al., 2015). Sensory stimulants enhance perceptions (Pine \& Gilmore, 1998).

\subsubsection{The Effective Dimension}

The practical or mental aspect relates to the customers' emotional interaction with a brand (Cho et al., 2015), as shown by their favorable disposition toward the brand and its durability (Kemp et al., 2014). This dimension 
encapsulates the customers' moods and emotions (Zarantonello \& Schmitt, 2013) when considering the brand and, for instance, embraces the positive effect as exhibited by the customers' amusement, joy, closeness, or passion (Thomson, MacInnis, \& Park, 2005).

As emotional stimulants, consumption-long emotions make the customers' interactions memorable (Iglesias et al., 2011).

\subsubsection{The Intellectual Dimension}

This intellectual and cognitive aspect illustrates how the brand evokes centered and cognitive critical methods and specific imaginative thoughts (Zarantonello \& Schmitt, 2013). The intellectual dimension involves the evaluation of non-product attributes (such as prices) and functional benefits (such as safety), and symbolic benefits (such as prestige) irrespective of whether these are direct or indirect (Cho et al., 2015). This dimension may be influenced through past or gift company experiences. Therefore, this process can reduce uncertainty and can raise expectations of performance (Hsu \& Cai, 2009) and, thereby, be reminders of the customers' loyalty towards the brand. An indication of suspense, anticipation, enthusiasm, learning, or evoking interest draws the intellectual element (Manthiou et al., 2015).

\subsubsection{The Behavioral Dimension}

Brand experience encompasses both company-motivated behaviors and either tangible or physical relationships with the brand (Zarantonello \& Schmitt, 2013). The amount of existing shopping or buying preferences is expressed in the rate and quantities of purchases (Cho et al., 2015). The company's reputation is affected by active or inactive customer involvement (Pine \& Gilmore, 1998). It is defined where other methods are suggested or whether a good or service is used (Machado et al., 2014; Manthiou et al., 2015).

\subsubsection{Product Versus Service Debate}

Vargo and Lusch (2008) consider the idea that experience is a business marketing term. It is widely accepted that it is particularly evident in the service industry how experience influences the customers' behaviors (Pullman \& Gross, 2004; Tynan \& McKechnie, 2009). Duncan and Moriarty (2006) suppose service itself can be the expertise in communications. They conclude that the key benefit of a touchpoint (brand point) is that it provides the knowledge: "When a consumer or potential consumer is connected to the brand, a market touchpoint is formed, and therefore a market experience is created." In order to offer customers experiences of service brands, it is necessary to create a relationship between customers and employees (Biedenbach \& Marell, 2010).

In terms of a combination of products and services brands, Brakus et al.'s (2009) dimension of brand experience has been accepted. Also, Iglesias et al.'s (2011) approval of the scale for three different products was implemented. Brakus et al.'s (2009) findings show that the commodity brands affect brand interactions with customer satisfaction, brand loyalty, and brand personality. Mosley (2007) suggests that brand experiences are more easily accessible than service impressions because brands are more multi-faceted and, in turn, are more connected. Marketing literature has been thinking about these differences in goods and services and offers explanations for such distinctions. Zeithaml et al. (1985) emphasize IHIP as an excellent service standard and describe such attributes as (1) heterogeneity-unstandardized services cannot be supplied; (2) intangibility-services do not have the intrinsic worth of products; (3) perishability-services cannot be stored; and (4) inseparability-services are distributed and utilized simultaneously.

\subsection{Brand Personality}

Significant work has been carried out over the past 15 years to identify and explain the context and the consequences of creating powerful brands (Aaker \& Biel, 1993). When competition has increased, and the demands among the various sectors and divisions offer similar alternatives to goods and services, branding has more and more outcomes and is regarded as a differentiating factor. On the other hand, its rational and functional aspects are assessed by the customer. Keller (2003) explains that branding is the process through which products and services are provided with features that, over time, can contribute to the creation of a powerful brand. According to this researcher, a brand presents a set of aspects that the customer views and, in doing so, creates several elements of brand awareness.

Keller $(1993,2003)$ states that brands and their dimensions have gained a great deal of attention, and the awareness of different brand organizations forms the bases for marketing strategies that support marketers in their decisions. The brand's strength lies in the customers' minds (brand awareness and image). As reported by Keller, Apéria, and Georgson (2008), experts and researchers must create for customers a complete map of brand details. Keller (1993) and Aaker (1996) consider the composition of brand awareness to be a compilation of each tangible/intangible and objective/subjective interaction that creates the brand image. 
Over the last decade, researchers have paid more attention to brand personality. Several scholars have questioned if products and brands may or may not have their own characteristics and whether or not these brands may bring to mind emotions, feelings, and attitudes in the same way as people are branded as outgoing, engaging, mindful, and smart (Caprara, Barbaranelli, \& Guido, 1998).

Since the 1950s, the field of sales has recognized that the product must accord with the customer's personality (Gardner \& Levy, 1955; Martineau, 1958; Levy, 1959). In addressing the creation of the product's image, DeToni and Schuler (2003) emphasize the product's personification: the product obtains the same personality as a person. During the 1980s, there was wide recognition of brand personality, and it became popular among marketeers and advertising professionals (Caprara et al., 1998). Sometimes, like human beings, brands are described, to name a few, as trendy, traditional, happy, or exotic. Often, although, in viewing a brand's personality, customers find themselves having to determine if the brand better represents them and matches their requirements.

\subsubsection{The Effects of Brand Personality}

As regards the impact of brand personality, earlier researches have shown that this factor plays an essential role in the relationship with the customer. In addition, it has the potential to create a distinctive brand personality within a given competitive marketplace (Ferrandi, Merunka, Valette-Florence, \& First State Barnier, 2002). Shank and Langmeyer's (1994) findings demonstrate that perceived brand personality can go much further and be separate from a customer's personality. Consequently, people with entirely different characteristics have a similar view of the product or brand personality. Recent research studies, which have focused on brand personality's gender dimensions, show that, once there is a consistent perceived brand image, the effect is positive as long as there is a favorable behavior towards brand preference over competitive brands (Grohmann, 1999).

\subsubsection{Brand Personality Dimensions}

Having regard to a series of studies, Aaker (1997) indicates that the five dimensions of brand personality are: competency (reliable, smart, and successful), sincerity (down-to-earth, honest, healthy, and cheerful), sophistication (high-class and charming), excitement (daring, spirited, ingenious, and up-to-date) and roughness (outdoors, and robust). All five dimensions come from entirely different brand sets and different product class sets; these suggest the generalization of these aspects. Following some criticism, after 1997, most brand personality research studies have used Aaker's (1997) scale (Azoulay \& Kapferer, 2003).

Even when the personality scale of the brand is based on a model of human personality (Aaker, 1997), the brand personality is analyzed by using a significantly different approach to human personality. This is because the two personality models have entirely different subjects and objectives. For example, brand personality is a customer relating to a product, while the human character's attributes are derived from the facial features and behavioral values.

Table 1. Aaker's brand personality dimensions

\begin{tabular}{ll}
\hline Dimensions & \\
\hline Sincerity & $\begin{array}{l}\text { Down-to-earth, Family-oriented, Small-town, Honest, Sincere, Real, } \\
\text { Wholesome, Original, Cheerful, Sentimental, Friendly } \\
\text { Earing, Trendy, Exciting, Spirited, Cool, Young, Imaginative, Unique, Up-to-date, } \\
\text { Independent, Contemporary }\end{array}$ \\
Competence & $\begin{array}{l}\text { Reliable, Hard-working, Secure, Intelligent, Technical, Corporate, } \\
\text { Successful, Leader, Confident }\end{array}$ \\
Sophistication & Upper Class, Glamorous, Good-Looking, Charming, Feminine, Smooth \\
Ruggedness & Outdoorsy, Masculine, Western, Tough, Rugged \\
\hline
\end{tabular}

Many recent research studies have determined a scale for the purpose of assessing and evaluating brand experience. Brand experience and perceptions have been strongly influenced by using the structural model, and, therefore, the influence of the brand's image has a direct effect on both customer retention and satisfaction (Brakus, Schmitt, \& Zarantonallo, 2009). According to the researchers, brand personality's social and self-expressive characteristics may account for their being treated as reference points of satisfaction and loyalty.

\section{Research Methodology}

In this section, the author tests the hypotheses, which were used to address the research questions, and discusses 
the systematic research methods.

By using brands (Vodafone Egypt, Orange Egypt, Etisalat Egypt, and We Egypt) that provide telecommunications services in Egypt, the author conducted experimental research to examine the effect of brand experience in the Egyptian telecommunications industry on brand personality and brand loyalty. The author carried out the research by using an online survey and, with the assistance of an online data provider (Google Form), managed to complete the investigation within six months

\section{Research Hypotheses}

The author drew on the literature mentioned above and theories to formulate the following hypotheses:

H1: Brand experience has a positive effect on brand personality in the Egyptian telecommunications industry.

$\mathrm{H} 2$ : Brand personality has a positive effect on brand loyalty in the Egyptian telecommunications industry.

H3: Brand experience has a positive effect on brand loyalty in the Egyptian telecommunications industry.

Table 2 illustrates the scales that the author adapted and modified from the literature. The model measures of variables were taken from the literature and changed to fit the purpose of this research study. For measurement purposes, this study used a 5-point Likert scale. Table 2 shows the sources of the measurements. Brand Experience and Brand Loyalty were measured on the Likert scale from one, which indicates "strongly disagree" to five, which indicates "strongly agree." The brand personality was measured from one to five on the Likert scale\# from stating "not at all descriptive" to "extremely descriptive." As shown in Table 1, Brakus et al. (2009) used the four dimensions of sensory, affective, intellectual, and behavioral to measure the brand experience. Aaker (1997) used the five aspects of sincerity, excitement, competence, sophistication, and ruggedness to measure brand personality. There are close relationships between the 15 facets that Aaker used to reflect the five dimensions.

The following three items measured, also, brand loyalty: I'll be loyal to 'Brand' in the future' (Brakus et al., 2009); 'I intend to continue to be' Brand 'customer for the next six months' (Pedersen \& Nysveen, 2001); and 'I will recommend others' on 'Brand' (Brakus et al., 2009).

Table 2. Adopted sources of scale

\begin{tabular}{lll}
\hline Variables & Dimensions & Source of scale \\
\hline Brand Experience & Intellectual, sensory, affective, behavioral & Barkus et al., 2009 \\
Brand Personality & Ruggedness, sincerity, sophistication, excitement, and competence. & Aaker, 1997 \\
\hline
\end{tabular}

In the Egyptian context, in order to make the English language more accessible to customers, the author made some adjustments to the wordings. For example, "down-to-earth" was changed to "simple," "wholesome" was changed to "beneficial," daring was changed to "courage," "spirited," was changed to "lively," "upper-class" was changed to "high-class" and "outdoorsy" was changed to "strong."

\section{Data Collection and Analyses}

The author used a simple sampling method to distribute the questionnaires to companies (Vodafone Egypt, Orange Egypt, Etisalat Egypt, and We Egypt) within the Egyptian telecommunications industry. Four hundred and fifty surveys were distributed, and, following the exclusion of incomplete surveys, there were 392 valid samples. This resulted in an $87 \%$ response rate.

The author used SPSS software V. 23 to analyze the data and to obtain the descriptive statistics. Cronbach's $\alpha$ was used to verify the reliability and the coefficients of correlation in internal consistency. While AMOS software V. 23 was used for the structural equation modeling. AMOS is structured for the estimation and testing of Structural Equation Models (SEMs), which are statistical models of the linear relationships between latent and manifest (observed) variables. It aims to assess the coefficients in a series of systemic equations. For this research study, the author used AMOS to investigate the causal relationships where the path coefficients were tested for significance and goodness-of-fit. The overall model fit measures were used to evaluate the fit of the structural model. The goodness-of-fit indices, which were used for measurement and structural models. Were $\chi^{\wedge} 2$ test, normed $\chi^{\wedge} 2$, Goodness of Fit Index (GFI), Normed Fit Index (NFI), Comparative Fit Index (CFI), and Root Mean Square Error of Approximation (RMSEA).

The standardized estimates were used to report the causal relationships between the exogenous and endogenous constructs. 


\section{Data Analysis and Results}

\subsection{Sample Profile}

Of a total sample of 392 respondents, $58.7 \%$ were female, and $41.3 \%$ were male. Most of the respondents' ages were in the ranges 25-33 (29.1\%), 34-41 (35.2\%) and 41-50 (32.7\%). Most of the respondents (41.3\%) used the Vodafone Company. Also, most of the respondents' (60.7) possessed undergraduate degrees. Table 3 displays the descriptive statistics

\subsection{Measurement Model}

The suggested structural model was estimated by SEM, which included a test of the model fitness and individual measures of the importance of the interactions between the variables.

Table 3. Descriptive statistics of the respondents' demographic characteristics

\begin{tabular}{llll}
\hline Variable & Frequency & $\mathbf{\%}$ & Cumulative \% \\
\hline I. Company & & & \\
Etisalat & 92 & 23.5 & 23.5 \\
Mobinil & 114 & 29.1 & 52.6 \\
Vodafone & 162 & 41.3 & 93.9 \\
WE & 24 & 6.1 & 100.0 \\
II. Gender & & & \\
Female & 230 & 58.7 & 58.7 \\
Male & 162 & 41.3 & 100.0 \\
III. Education & & & \\
College qualification (diploma/certificate) & 70 & 17.8 & 17.8 \\
Postgraduate degree (Master/PhD.) & 84 & 21.4 & 39.3 \\
Undergraduate degree & 238 & 60.7 & 100.0 \\
IV. Age & & & \\
More than 25 to 33 & 114 & 29.1 & 29.1 \\
More than 33 to 41 & 138 & 35.2 & 64.3 \\
More than 41 to 50 & 128 & 32.7 & 96.9 \\
More than 50 & 12 & 3.1 & 100.0 \\
\hline
\end{tabular}

Note. Frequency Tables.

The results of these tests indicate the relationship between brand experience, brand personality, and brand loyalty. The estimations of the parameters and the overall fit index of the measurement model are based on the Maximum Likelihood (ML) method. The underlying assumptions of the ML method (Byrne, 2001; El-Sheikhet et al., 2017) are met or closely approximated in this study. Further, the sample is sufficiently large $(n=392$ cases) being over the recommended size of 200 cases (Medsker et al., 1994); the scale of observed variables is continuous, and no violations of multivariate normality are found in the survey responses.

Table 4 presents the reliability of the measurement items that were verified by using Cronbach's $\alpha$ to assess the internal consistency of the model's constructs. The level of internal consistency for each construct is acceptable since each exceeds the minimum hurdle of 0.60 (Hair et al., 1998). All measurement items have standardized loading estimates (ranging from 0.536 to 0.962 ) higher than 0.5 ; this indicates the convergent validity of the measurement model. Also, Construct Reliability (CR) is verified in order to estimate convergent validity. In this respect, each construct has acceptable construct reliability because all three constructs (ranging from 0.788 to 0.924) exceed the minimum criterion of 0.5 (Hair et al., 1998). Moreover, because the Average Variance Extracted (AVE) from all three constructs (ranging from 0.501 to 0.792 ) exceeds the minimum criterion of 0.5 , convergent validity is assured (Hair et al., 1998).

The author estimated correlations among the constructs in order to test the discriminant validity among the constructs and to determine whether they were significantly different from 1 . The confidence intervals of the correlations, calculated as (correlations estimate $+1.96 \times$ standard error of estimate), do not contain one and, therefore, these results indicate the discriminant validity of the measurement model.

Table 5 shows the correlations of the structures. Generally, these measurement findings are satisfactory and indicate that it is reasonable to continue with the evaluation of the structural model. 
Table 4. Properties of measures (convergent validity and reliability)

\begin{tabular}{|c|c|c|c|c|c|c|c|}
\hline Construct & Item & Standardized loading & Mean & SD & Cronbach's $\alpha$ & $\mathrm{CR}$ & AVE \\
\hline \multirow[t]{5}{*}{ Brand experience } & & & 2.7581 & .55160 & .767 & .788 & .501 \\
\hline & Sensory & .536 & 2.9456 & .56527 & & & \\
\hline & Affective & .877 & 2.7126 & .83009 & & & \\
\hline & Behavioral & .614 & 2.6633 & .78446 & & & \\
\hline & Intellectual & .684 & 2.7109 & .66583 & & & \\
\hline \multirow[t]{6}{*}{ Brand personality } & & & 3.2333 & .93174 & .925 & .924 & .712 \\
\hline & Sincerity & .705 & 3.0816 & .93629 & & & \\
\hline & Excitement & .840 & 3.2526 & 1.02937 & & & \\
\hline & Competence & .962 & 3.2968 & 1.19421 & & & \\
\hline & Sophistication & .922 & 3.4413 & 1.16261 & & & \\
\hline & Ruggedness & .763 & 3.0944 & .96078 & & & \\
\hline Brand loyalty & & & 3.3724 & 1.30183 & .875 & .921 & .796 \\
\hline
\end{tabular}

Note. CR, construct reliability; AVE, average variance extracted. Cronbach's $\alpha$ of all constructs is .908 .

Table 5. Correlation matrix and the discriminant validity

\begin{tabular}{llll}
\hline & Brand Loyalty & Brand Experience & Brand personality \\
\hline Brand Loyalty & 1 & $.291^{* *}$ & $.851^{* *}$ \\
Brand Experience & $.291^{* *}$ & 1 & $.300^{* *}$ \\
Brand personality & $.851^{* *}$ & $.300^{* *}$ & 1 \\
\hline
\end{tabular}

Note. ${ }^{* *}$ significant at the $\mathrm{p}<0.01$ level (two-tailed).

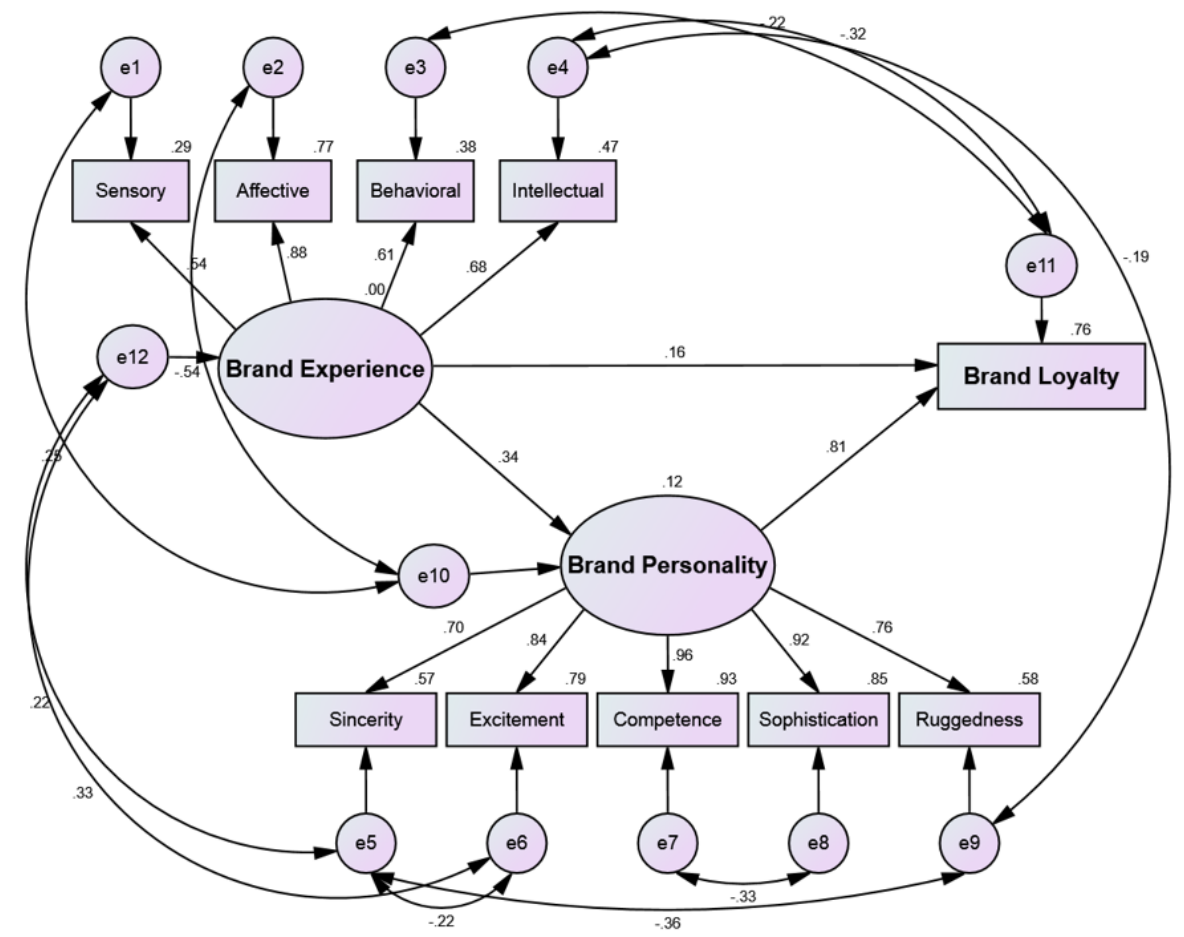

Figure 1. The proposed model's standardized regression coefficients

\subsection{Structural Model}

Figure 1 shows the overall explanatory power and the standardized path regression coefficients that indicate the direct influences of the predictor upon the research model's predicted latent constructs. Table 6 presents the structural model's fit indices and the cut-off value of those fit indices. The goodness-of-fit statistics show that the structural model fits the data reasonably well. 
Table 6. Model fit statistics

\begin{tabular}{lll}
\hline Structural model & Fit statistics & Cut-off value \\
\hline$\chi^{2}$ & 20.886 & ----- \\
p-value of $\chi^{2}$ & .588 & $>0.05$ \\
Normed $\chi^{2}$ & .908 & $<3.00$ \\
Goodness of Fit Index (GFI) & .979 & $>0.90$ \\
Normed Fit Index (NFI) & .986 & $>0.90$ \\
Comparative Fit Index (CFI) & .998 & $>0.90$ \\
Root Mean Square Error of Approximation (RMSEA) & .001 & $<0.09$ \\
\hline
\end{tabular}

Table 7 presents the results of the individual tests of the significance of the relationship among the variables. Among the three tested relationships, the findings show that three relationships are significant at a significant level of 0.01 . Brand experience has a significantly positive effect on brand personality with $\beta=.745, t=3.827$, and $p$-value $<0.001$; this indicates that brand personality is a significant antecedent of brand personality. Brand experience has, also, a strong positive effect on Brand loyalty $(\beta=.687, t=3.390$, and $p$-value $<0.001)$. Finally, brand personality has a strong positive impact on brand loyalty, with $\beta=1.593, \mathrm{t}=11.785$, and $\mathrm{p}$-value $<0.001$; this indicates that brand personality is an antecedent of brand loyalty.

As shown by the results in Table 8, the author analyzed the standardized direct, indirect, and total effects in order to examine the interplay between the two variables that affect brand loyalty. The direct effect of brand experience on brand loyalty $(0.160)$ is particularly interesting. The analysis indicates, also, that brand experience has an indirect impact $(0.276)$ on brand loyalty through its impact on brand personality.

Table 7. The research model's maximum likelihood estimates $(n=392)$

\begin{tabular}{llllllll}
\hline Hypothesis & $\begin{array}{l}\text { Independent } \\
\text { variable }\end{array}$ & Dependent variable & $\begin{array}{l}\text { Standardized } \\
\text { estimate }\end{array}$ & Estimate & $\begin{array}{l}\text { Standard } \\
\text { error }\end{array}$ & t-statistic & p-value \\
\hline $\mathbf{H}_{\mathbf{1}}$ & Brand experience & Brand personality & .342 & .745 & .195 & 3.827 & $* * *$ \\
$\mathbf{H}_{\mathbf{2}}$ & Brand personality & Brand loyalty & .806 & 1.593 & .135 & 11.785 & $* * *$ \\
$\mathbf{H}_{\mathbf{3}}$ & Brand experience & Brand loyalty & .160 & .687 & .203 & 3.390 & $* * *$ \\
\hline
\end{tabular}

Note. ${ }^{* * *}$ significant at the $\mathrm{p}<0.001$ level (two-tailed).

Table 8. Decomposition of the research model's total effects

\begin{tabular}{lllll}
\hline Independent variable & Dependent variable & Direct effect & Indirect effect & Total effect \\
\hline Brand experience & Brand personality & .342 & .000 & .342 \\
Brand personality & Brand loyalty & .806 & .000 & .806 \\
Brand experience & Brand loyalty & .160 & .276 & .436 \\
\hline
\end{tabular}

\section{Conclusion and Implications}

In this research study, the author examined in the context of the Egyptian telecommunications market the relationship between Brakus et al.'s (2009) four experience dimensions (sensory, behavioral, intellectual, and affective), brand personality, and brand loyalty.

In conducting this study, the author used an online questionnaire that was distributed to companies (Vodafone Egypt, Orange Egypt, Etisalat Egypt, and We Egypt) within the Egyptian telecommunications industry. Based on a simple sampling method, four hundred and fifty surveys were distributed and, after excluding incomplete questionnaires, 392 samples were obtained. This represented an $87 \%$ response rate participate.

In conclusion, within the Egyptian telecommunication industry, the author was able to test the study's three hypotheses. The results reveal that brand experience has a positive impact on the brand's personality. Brand experience has, also, a strong positive effect on brand loyalty and, eventually, brand personality has a robust positive impact on brand loyalty. Besides the direct influence of brand experience on brand loyalty, it has a significant indirect effect on brand loyalty through impacting on brand personality. The relationship between brand personality and brand loyalty is the strongest among the variables, as can be observed from the consistency of the findings. These show that the indirect relationship between brand experience and brand loyalty is more reliable than the direct link. Consequently, telecommunications managers should pay more attention to the nature of the customer brand personality so that they can increase loyalty to the brand. The 
sensory experience structure illustrates the value of enhancing and pleasing to the customers' senses. Therefore, Egyptian telecommunications companies should attempt to make whole elements visually exciting and appealing in order to improve brand personality and brand loyalty. These visual aesthetic effects impact on the customers' responses (Rindova \& Petkova, 2007).

Intellectual experience may be a feature of the amount of thought required when dealing with the brand and the extent to which the brand encourages curiosity and problem solving (Brakus et al., 2009). If a brand leads to a lot of thought, this can be a cause for enhancing the brand's mental image and influencing brand personality and brand loyalty. Therefore, it is essential that the next generation of telecommunications services pay greater attention to this concept.

\section{References}

Aaker, D. (1996). Raising and managing event marks. São Paulo: Future.

Aaker, D., \& Biel, A. (1993). Brand Equity and Advertising: an overview. In D. Aaker \& A. Biel (Eds.), Brand equity and advertising (pp. 1-8). New Jersey: Lawrence Erlbaum Associates.

Arnould, E. J., Linda, L. P., \& George, L. Z. (2002). Consumers (2nd ed.). New York: McGraw-Hill/Richard D. Irwin.

Azoulay, A., \& Kapferer, J. N. (2003). Do brand personality scales measure brand personality? Brand Management, 11(2), 143-155. https://doi.org/10.1057/palgrave.bm.2540162

Biedenbach, G., \& Marell, A. (2010). The Impact of Customer Experience on Brand Equity in a Business-to-Business Services Setting. Journal of Brand Management, 17(6), 446-458. https://doi.org/10.1057/bm.2009.37

Brakus, J. J., Bernd, H. S., \& Shi, Z. (2008). Experiential Attributes and Consumer Judgments. In B. H. Schmitt \& D. Rogers (Eds.), Handbook on Brand and Experience Management. Northampton, MA: Edward Elgar.

Brakus, J. J., Schmitt, B. H., \& Zarantonello, L. (2009). Brand experience: What is it? How is it measured? Does it affect loyalty? Journal of Marketing, 73(3), 52-68. https://doi.org/10.1509/jmkg.73.3.52

Byrne, B. M. (2001). Structural Equation Modelling with AMOS: Basic Concepts, Applications, and Programming. Lawrence Erlbaum Associates, Mahwah, NJ.

Caprara, G. V., Barbaranelli, C., \& Guido, G. (1998). Personality as metaphor: extension of the psychological hypothesis and the five-factor model to brand and product personality description. European Advances in Consumer Research, 3, 61-69.

Chattopadhyay, A., \& Jean-Louis, L. (2005). Managing Brand Experience: The Market Contact Audit ${ }^{\mathrm{TM}}$. Journal of Advertising Research, 45(1), 9-16. https://doi.org/10.1017/S0021849905050129

Cho, E., Fiore, A. M., \& Russell, D. W. (2015). Validation of a fashion brand image scale capturing cognitive, sensory, and affective associations: Testing its role in an extended brand equity model. Psychology \& Marketing, 32(1), 28-48. https://doi.org/10.1002/mar.20762

De Toni, D., \& Schuler, M. (2003, September). Imagem de produto e comportamento do consumidor: explorando o processo de formação das imagens (p. 27). Proceedings of the Encontro Nacional da Associação Nacional de Pós-Graduação e Pesquisa em Administração, Atibaia, SP, Brazil.

Duncan, T., \& Moriarty, S. (2006). How Integrated Marketing Communication's "Touchpoints" Can Operationalize the Service-Dominant Logic. In R. F. Lusch \& L. Stephen (Eds.), The Service-Dominant Logic of Marketing. Vargo: Armonk, N.Y.: M.E. Sharpe.

Ekström, K. (2010). Consumer behaviour: A nordic perspecitve. Lund, Sweden: Studentlitteratur.

El-Sheikh, A. A., Abonazel, M. R., \&Gamil, N. (2017). A Review of Software Packages for Structural Equation Modeling: A Comparative Study. Applied Mathematics and Physics, 5(3), 85-94.

Ferrandi, J. M., Merunka, D., Valette-Florence, P., \& De Barnier, V. (2002). Brand personality: how well does a human personality scale apply to brands? Asia Pacific Advances in Consumer Research, 5, 53-60.

Fishbein, M., \& Ajzen, I. (1975). Belief, Attitude, Intention, and Behavior: An Introduction to Theory and Research, Reading. Mass.: Addison-Wesley.

Gardner, B. B., \& Levy, S. J. (1955). The product and the brand. Harvard Business Review, 33(2), 33-39. https://doi.org/10.1016/0737-6782(88)90037-9 
Grohmann, B. (2009). Gender dimensions of brand personality. Journal of Marketing Research, 46(1), 105-119. https://doi.org/10.1509/jmkr.46.1.105

Hair, J. F., Anderson, R. E., Tatham, R. L., \& Black, W. C. (1998). Multivariate Data Analysis (5th ed.). Prentice-Hall, Upper Saddle River, NJ.

Holbrook, M. B. (2000). The Millennial Consumer in the Texts of Our Times: Experience and entertainment. Journal of Macromarketing, 20(2), 178-192. https://doi.org/10.1177/0276146700202008

Hsu, C., \& Cai, L. A. (2009). Brand knowledge, trust, and loyalty - A conceptual model of destination branding. International CHRIE Conference-Refereed Track.

Iglesias, O., Singh, J. J., \& Batista-Foguet, J. M. (2011). The role of brand experience and affective commitment in determining brand loyalty. Journal of Brand Management, 18(8), 570-582. https://doi.org/10.1057/bm.2010.58

Japutra, A., Ekinci, Y., \& Simkin, L. (2014). Exploring brand attachment, its determinants, and outcomes. Journal of Strategic Marketing, 22(7), 616-630. https://doi.org/10.1080/0965254X.2014.914062

Joy, A., \& Sherry, J. (2003). Speaking of art as embodied imagination: A multisensory approach to understanding aesthetic experience. Journal of Consumer Research, 30(2), 259-282. https://doi.org/10.1086/376802

Keller, K. L. (1993). Conceptualizing, measuring, and managing customer-based brand equity. Journal of Marketing, 57(1), 1-22. https://doi.org/10.2307/1252054

Keller, K. L. (2003). Brand synthesis: The multidimensionality of brand knowledge. Journal of Consumer Research, 29(4), 595-600. https://doi.org/10.1086/346254

Keller, K. L., Aperia, T., \& Georgson, M. (2008). Strategic brand management: A European perspective. Harlow: Pearson Education Limited.

Kemp, E., Jillapalli, R., \& Becerra, E. (2014). Healthcare branding: developing emotionally based, consumer-brand relationships. Journal of Services Marketing, 28(2), 126-137. https://doi.org/10.1108/JSM-08-2012-0157

Klaus, P., \& Maklan, S. (2012). EXQ: A multiple-item scale for assessing service experience. Journal of Service Management, 23(1), 5-33. https://doi.org/10.1108/09564231211208952

Levy, S. J. (1959). Symbols for sales. Harvard Business Review, 37(4), 117-124.

Lind, D. A., Marshal, W. G., \& Wathen, S. A. (2008). Statistical Techniques in Business \& Economics: With Global Data Sets (13th ed., p. 317). McGraw-Hill.

Machado, R., Can't, M. C., \& Seaborne, H. (2014). Experiential marketing on brand advocacy: A mixed-method approach on global Apple product users. International Business \& Economics Research Journal (IBER), 13(5), 955-962. https://doi.org/10.19030/iber.v13i5.8764

Manthiou, A., Kang, J., Sumarjan, N., \& Tang, L. R. (2015). The incorporation of consumer experience into the branding process: An investigation of name-brand hotels. International Journal of Tourism Research. https://doi.org/10.1002/jtr.2037

Martineau, P. (1958). The personality of the retail store. Harvard Business Review, 36(1), 47-55.

Medsker, G. J., Williams, L. J., \& Holahan, P. J. (1994). A review of current practice for evaluating causal models in organizational behavior and human resources management research. Journal of Management, 20, 439-464. https://doi.org/10.1177/014920639402000207

Meyer, C., \& Schwager, A. (2007). Understanding Customer Experience. Harvard Business Review, 85, 137.

Mosley, R. W. (2007). Customer experience, organizational culture, and the employer brand. Journal of Brand Management, 15(2), 123-134. https://doi.org/10.1057/palgrave.bm.2550124

Pine, B. J., \& Gilmore, J. H. (1998). Welcome to the experience economy. Harvard Business Review, 76(4), 97-105.

Pullman, M. E., \& Gross, M. A. (2004). Ability of Experience Design Elements to Elicit Emotions and Loyalty Behaviors. Decision Sciences, 35(3), 551-578. https://doi.org/10.1111/j.0011-7315.2004.02611.x

Rageh Ismail, A., Melewar, T. C., Lim, L., \& Woodside, A. (2011). Customer experiences with brands: Literature review and research directions. The Marketing Review, 11(3), 205-225. https://doi.org/10.1362/146934711X589435 
Reimann, M., Zaichkowsky, J., Neuhaus, C., Bender, T., \& Weber, B. (2010). Aesthetic package design: A behavioral, neural, and psychological investigation. Journal of Consumer Psychology, 20(4), 431-441. https://doi.org/10.1016/j.jcps.2010.06.009

Rindova, V. P., \& Petkova, A. P. (2007). When is a new thing a good thing? Technological change, product form design, and the perception of value for product innovations. Organizational Science, 18(2), $217-232$. https://doi.org/10.1287/orsc.1060.0233

Roswinanto, W., \& Strutton, D. (2014). Investigating the advertising antecedents to and consequences of brand experience. Journal of Promotion https://doi.org/10.1080/10496491.2014.946206

Schmitt, B. H. (2003a). Customer Experience Management: A Revolutionary Approach to Connecting with Your Customers. Hoboken, N.J.: Wiley.

Schmitt, B. H. (2003b). Customer Experience Management. New York: John Wiley \& Sons.

Schmitt, B. H. (2012). The consumer psychology of brands. Journal of Consumer Psychology, 22(1), 7-17. https://doi.org/10.1016/j.jcps.2011.09.005

Shamim, A., \& Mohsin, B. M. (2013). A critical model of brand experience consequences. Asia Pacific Journal of Marketing and Logistics, 25(1), 102-117. https://doi.org/10.1108/13555851311290957

Shank, M. D., \& Langmeyer, L. (1994). Does personality influence the brand image? The Journal of Psychology, 128(2), 157-164. https://doi.org/10.1080/00223980.1994.9712719

Shaw, C., \& John, I. (2002). Building Great Customer Experiences. New York: Palgrave/Macmillan. https://doi.org/10.1057/9780230554719

Smith, S., \& Joe, W. (2002). Managing the customer experience: Turning Customers into Advocates. Upper Saddle River, NJ: Financial Times/Prentice Hall.

Thomson, M., MacInnis, D. J., \& Park, C. W. (2005). The ties that bind: measuring the strength of consumers' emotional attachments to brands. Journal of Consumer Psychology, 15(1), 77-91. https://doi.org/10.1207/s15327663jcp1501_10

Tynan, C., \& McKechnie, S. (2009). Experience Marketing: A Review and Reassessment. Journal of Marketing Management, 25(5/6), 501-517. https://doi.org/10.1362/026725709X461821

Vargo, S. L., \& Lusch, R. F. (2008). Why "Service”? Journal of the Academy of Marketing Science, 36(1), 25-38. https://doi.org/10.1007/s11747-007-0068-7

Walls, A. R. (2013). A cross-sectional examination of hotel consumer experience and relative effects on consumer values. International Journal of Hospitality Management, 32, 179-192. https://doi.org/10.1016/j.ijhm.2012.04.009

Zarantonello, L., \& Schmitt, B. H. (2013). The impact of event marketing on brand equity. International Journal of Advertising, 32(2), 255-280. https://doi.org/10.2501/IJA-32-2-255-280

Zeithaml, V. A., Parasuraman, A., \& Berry, L. L. (1985). Problems and strategies in service marketing. Journal of Marketing, 49(2), 33-46. https://doi.org/10.1177/002224298504900203

\section{Copyrights}

Copyright for this article is retained by the author, with first publication rights granted to the journal.

This is an open-access article distributed under the terms and conditions of the Creative Commons Attribution license (http://creativecommons.org/licenses/by/4.0/). 